\title{
Karyotypes in Species of Eryngium in Argentina
}

\author{
Alicia Nasif*, Adriana Pastoriza, Laura Martinez Pulido, \\ Salvador Chaila and Carlos Jorge Budeguer \\ Faculty of Agronomy and Zootechny, National University of Tucumán, \\ Avenida Kirchner 1900, 4000, San Miguel de Tucumán, Argentina
}

Received December 17, 2011; accepted July 6, 2012

\begin{abstract}
Summary The objective of this study is to analyse the karyotype to determine the chromosomal asymmetry and its relationship with the evolution of species of Eryngium: E. elegans Cham et Schlecht, E. ebracteatum Lam., E. horridum Malme and E. coronatum Hook \& Arn. in Argentina. E. elegans, E. ebracteatum and $E$. horridum have $2 n=16$, and $E$. coronatum has $2 n=48$, with relatively symmetric karyotypes. It is suggested that the studied species had great adaptation to diverse environmental conditions reaching a great invasive power and aggressiveness as weeds, keeping their karyotype through the evolution.
\end{abstract}

Key words Asymmetry, Evolution, Eryngium, Karyotype, Argentina.

Genus Eryngium (Apiaceae) has about 3000 species with an ample reproduction and adaptation capacity for prospering in warm subtropical and temperate climates in South America and Europe. The genus is presented in the South American countries of Argentina, Bolivia, Paraguay, Uruguay and Brazil. In the Argentinean northwest, especially in Tucumán province, several species of the genus acquired importance as weeds with great invasive power, affecting economically important crops, like sugarcane (Chaila and Sobrero 2009).

E. elegans Cham \& Schlecht, E. ebracteatum Lam., E. coronatum Hook. \& Arn. and E. horridum Malme are noted species because they represent important weeds for the Argentinean northwest (Rochi and Lallana, 1996, Nasif et al. 2001, 2003, Andrada et al. 2001a, Lorenzi 2000). From a phenotypic point of view, the 4 species have ample genetic variability indicated by means of isoenzyme markers which favour their ample invasive capacity (Andrada et al. 2001b, Pastoriza et al. 2009). From a cytogenetic point of view, Darlington and Wylie (1955) cited for the genus a basic number $x=8$ with diploid $(2 n=16)$, tetraploid $(2 n=32)$ and hexaploid $(2 n=48)$ species. Silveira Vianna and Irgang (1971) mentioned the existence of a high polyploidy and aneuploidy percentage for Apiaceae and proposed at least 3 basic numbers for Rio Grande do Sul (Brazil). Perdigo I Ariso (1981) reported the existence of diploid species with chromosome numbers varying from $2 n=14$ to $2 n=16$ and tetraploid species with $2 n=28$ and $2 n=32$. Further, Constance (1982) determined that the half of the genus chromosome numbers were multiples of $n=8$, with some species having $n=5-8$ and the possibility of inter specific hybridisations. Calviño et al. (2001) cited for E. coronatum and E. horridum the number $2 n=16$, and also pointed that polyploidy and chromosome rearrangement would be important in the genus speciation. In the same sense, Nasif et al. (2000, 2001, 2003) reported for E. elegans, E. ebracteactum and E. horridum regular chromosome behaviour during the different meiosis stages with the presence of great quantities of open bivalents and also high pollen fertility. The same behaviour was observed in hexaploid species of E. coronatum showing characteristics of a diploid species (Andrada et al. 2001).

\footnotetext{
* Corresponding author, e-mail: aliciamn2002@yahoo.com.ar DOI: $10.1508 /$ cytologia. 77.369
} 

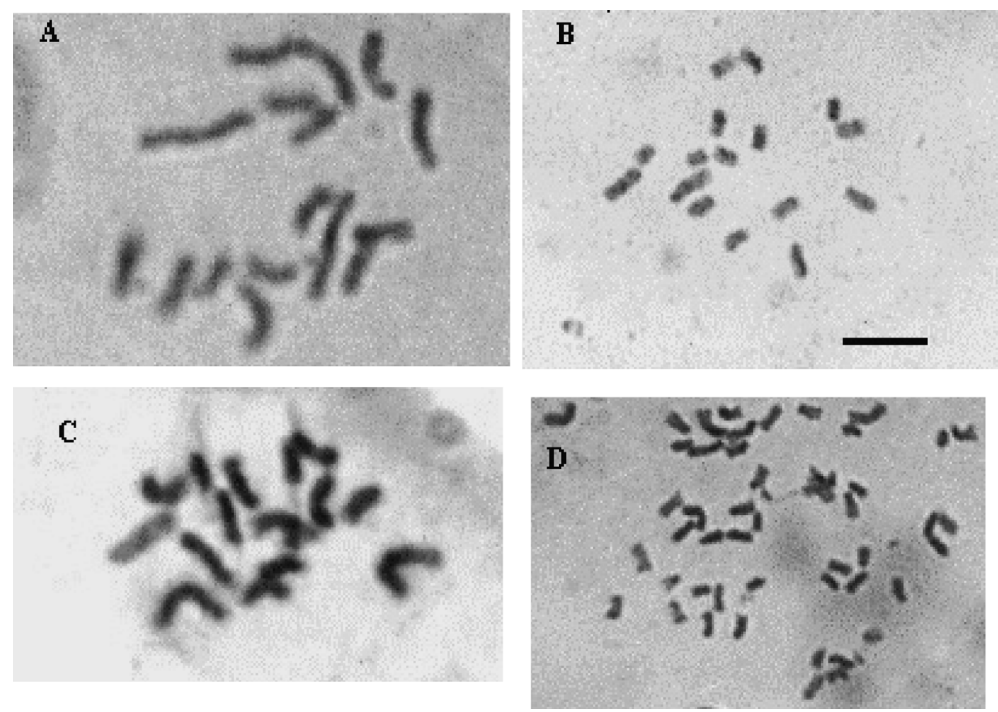

Fig. 1. Mitotic chromosomes of 4 Argentinean Eryngium species. A, E. elegans Cham \& Schlecht.; B, E. ebracteatum Lam.; C, E. horridum Malme.; D, E. coronatum Hook. \& Arn. Scale bar $=4 \mu \mathrm{m}$.

The objective of this work is to analyse the chromosome complement, to realize the karyotype, to determine intra- and inter-specific chromosome asymmetry of 4 species of Eryngium genus that constitute the most common weeds of the Argentinean northwest: E. elegans Cham \& Schlecht, E. ebracteatum Lam, E. horridum Malme and E. coronatum Hook. \& Arn.

\section{Materials and methods}

The material of E. elegans and E. ebracteatum came from La Rinconada, located at the piedmont zone of Tucumán province (Argentina). The material of E. coronatum and E. horridum came from Santiago del Estero province (Argentina). All plants were maintained in pots in the greenhouse at the Facultad de Agronomía and Zootecnia of the Universidad Nacional de Tucumán. For the preparation of the samples, the root tips were pretreated with a saturated solution of paradichlorobenzene for $2.5 \mathrm{~h}$. Then, they were fixed in a mixture of $3: 1$ (absolute ethylic alcohol: glacial acetic acid). Further, the root tips were hydrolysed in $1 \mathrm{~N} \mathrm{HCl}$ at $58-60^{\circ} \mathrm{C}$ for $8 \mathrm{~min}$ and were conserved at $45 \%$ acetic acid. To finish the preparations, the root tips were squashed in a drop of $2 \%$ haematoxylin (Nasif et al. 2003). The karyotype of each species was taken from microphotographs in $3000 \times$. The calculus of the intra and inter chromosome asymmetry (A1 and A2) was carried out according to Romero Zarco (1986).

\section{Results and discussion}

Chromosomal numbers determined for E. elegans, E. ebracteatum and E. horridum were $2 n=16$, and for $E$. coronatum was $2 n=48$, as shown in Figs. 1 and 2. In diploid species, morphology corresponds to that of metacentric and sub-metacentric chromosomes. Chromosome size was from small to medial and low values of asymmetry indexes were obtained. In E.coronatum, the karyotype was composed with medial and sub medial centromeres and the chromosome size was small and low asymmetry values. The karyotype formula of E. elegans is $8 \mathrm{~m}+8 \mathrm{sm}$, that of E. ebracteatum and E. horridum is $10 \mathrm{~m}+6 \mathrm{sm}$, and that of E. coronatum is $30 \mathrm{~m}+18 \mathrm{sm}$. The comparative values of all considered parameters in the karyotype study and life cycles of all species are presented 
Table 1. Comparative values of kariotypic parameters and their life cycle for the Eryngium species.

\begin{tabular}{lcccccc}
\hline \hline $\begin{array}{l}\text { Species of } \\
\text { Eryngium }\end{array}$ & $\begin{array}{c}\text { Life } \\
\text { cycle }\end{array}$ & $2 n$ & $\begin{array}{c}\text { Karyotypic } \\
\text { formula }\end{array}$ & $\begin{array}{c}\text { Size } \\
(\mu \mathrm{m})\end{array}$ & A1 & A2 \\
\hline E. elegans & Perennial & 16 & $8 \mathrm{~m}+8 \mathrm{sm}$ & $1.8-4$ & 0.29 & 0.20 \\
E. ebracteatum & Perennial & 16 & $10 \mathrm{~m}+6 \mathrm{sm}$ & $1.6-3.6$ & 0.27 & 0.28 \\
E. horridum & Perennial & 16 & $10 \mathrm{~m}+6 \mathrm{sm}$ & $1.3-2.4$ & 0.20 & 0.55 \\
E. coronatum & Perennial & 48 & $30 \mathrm{~m}+18 \mathrm{sm}$ & $1.6-3.4$ & 0.20 & 0.40 \\
\hline
\end{tabular}

in Table 1. In all species the mean chromosome length was similar with a range from 1.3 to $4.0 \mu \mathrm{m}$. In relation to the chromosome morphology, the presence of SAT chromosomes in pair 2 was observed in all species.

E. elegans, E. ebracteatum and E. horridum species are considered diploid according to their basic number of $x=8$, established by Darlington and Wylie (1955). The chromosome size and their numbers constituted vantages for the confection of the respective karyotypes and permitted the establishment of differences at that level among the species.

The chromosome number $2 n=48$ found in E. coronatum supports the notion that it is a hexaploid species (Andrada et al. 2001). These results differ from $2 n=16$ for this species (Calviño et al. 2001).

In spite of the 3 diploid species having similarity in the cytogenetic parameters analysed, they present very different plant morphology, according to the reports by Rochi and Lallana (1996) and Nasif et al. (1999). These morphological differences in plants were also confirmed by the intra and inter population variability determined by means of isoenzymatic markers (Pastoriza et al. 2009). The similarities in the chromosomal number found and in the shape (metacentric and submetacentric) from diploid species suggest that they could come from a common ancestor. The low values of intra and inter asymmetry (A1 and A2) obtained in all studied species indicate the tendency of the chromosomes to present centromeres predominantly from medial to sub medial positions. According to this, the result is that they present relatively symmetric karyotypes, the value A2 of E. horridum (0.55) being slightly superior indicating a little asymmetry. It would therefore appear that these species have been able to achieve great adaptability to different environmental conditions, and also a great invasive and aggressive power as weeds, while keeping their karyotypes constant throughout their evolution.

\section{Acknowledgments}

Thanks are extended to Consejo de Investigaciones of the Universidad Nacional de Tucumán 
(CIUNT), Tucumán, Argentina.

\section{References}

Andrada, B., Nasif, A., Martínez Pulido, L., Pastoriza, A., Schugurensky, A. and Chaila, S. 2001a. Citogenética en Eryngium coronatum Hook et Arn. XV Congreso de la Asociación Latinoamericana de Malezas. Libro de Resúmenes.

- , - Pastoriza, A. and Chaila, S. 2001b. Isoenzymatic characterization of Eryngium elegans Cham. et Schlecht populations of Tucumán province, Argentina. Pak. J. Bot. 33: 27-34.

Calviño, C., O'Leary, N., Martínez, S., Greizenstein, E. and Poggio, L. 2001. Estudios cromosómicos en siete especies argentines de Eryngium L. (Umbeliferae). J. Basic Appl. Genet. Actas XXX Congreso Argentino de Genética. Mar del Plata 15: 81 .

Chaila, S. and Sobrero, M. T. 2009. Principales malezas en el cultivo de la caña de azúcar. $1^{\text {a }}$ Ed. Santiago del Estero.

Constance, L. 1982. Some problems in New World Eryngium: Evolution, Classification, Ploidy, Chromosome Numbers, Identity and Distribution, History. Monographs in Systematic Botany from the Missouri Botanical Garden 6: $7-19$.

Darlington, C. D. and Wyle A. P. 1955. Chromosome Atlas of Flowering Plants. George Allen and Unwin Ltd., London.

Lorenzi, H. 2000. Plantas Daninhas do Brasil. Terrestres, Aquaticas, Parasitas e Toxicas. 3rd Ed. Instituto Plantarum, Nova Odessa.

Nasif, A. M., Andrada, A. B., Chaila, S., Pastoriza, A. 1999. Interpretación citogenética de las posibilidades de difusión de Eryngium elegans Cham. Et Schlechtd en el noroeste de Argentina. Actas de las XIV Jornadas de la Asociación Latinoamericana de Malezas (ALAM). Colombia.

-, Pastoriza, A., Martínez Pulido, L. and Chaila, S. 2000. Chromosomes of Eryngium ebracteactum Lam. and their behavior during meiosis. Biocell 24 (1): 118.

- , - Andrada, A. B., Martinez Pulido, L. and Chaila, S. 2001. Análisis de cromosomas mitóticos en especies del género Eryngium L. In: Facultad de Agronomía y Zootecnia, Universidad Nacional de Tucumán (ed.). II Reunión de Producción Vegetal del Noroeste Argentino. Avances en la Producción Vegetal del Noroeste Argentino. Memorias. Facultad de Agronomía y Zootecnia, Universidad Nacional de Tucumán, Tucumán. pp. 12-14.

—, Andrada, A. B., Chaila, S. and Pastoriza, A. 2003. "Estudios citogenéticos y de fertilidad de polen en Eryngium elegans Cham. et Schlecht”. An ales de Botánica Agrícola 10: 5-8.

Pastoriza, A., Andrada, A., Nasif, A., Martínez Pulido, L. and Chaila, S. 2009. Patrones electroforéticos de las actividades de peroxidasas y esterasas entre poblaciones de Eryngium ebracteatum Lam. del nordeste argentino. Anales de Botánica Agrícola 14: 16-21.

Perdigo I Ariso, M. T. 1981. Contributín a 'etude cytotaxinomique du genere Eryngium L.. Biologie-Ecologie méditerranéenne. 8: 3-12.

Rochi, G. R. and Lallana, V. H. 1996. Análisis del crecimiento aéreo y radical de plantas de "Caraguatá" (Eringium paniculatum Cav. \& Domb). Ciencia, Docencia y Tecnología 12: 137-150.

Romero Zarco, C. 1986. A new method for estimating karyotype asymmetry. Taxon: 35: 526-530.

Silveira Vianna, F. M. and Irgang, B. E. 1971. Levantamento do número cromossômico em espécies do gênero Eryngium L. (Umbelliferae) do Rio Grande Do Sul. I. Iheringia, Ser. Bot. 15: 49-51. 